\title{
Employer Branding: Moulding Desired Perceptions in Current and Potential Employees
}

\author{
Tosin Oladipo ${ }^{1}$, Jeremiah Iyamabo ${ }^{2} \&$ Olutayo Otubanjo ${ }^{2}$ \\ ${ }^{1}$ School of Media \& Communication, Pan-African University, Lagos, Nigeria \\ ${ }^{2}$ Lagos Business School, Pan-African University, Lagos, Nigeria \\ Correspondence: Jeremiah Iyamabo, Researcher, Lagos Business School, Pan-African University, Km 22, \\ Lekki-Epe Expressway, Ajah, Lagos, Nigeria. Tel: 234-810-323-5988. E-mail: jiyamabo@lbs.edu.ng
}

\author{
Received: February 21, 2013 Accepted: March 5, 2013 Online Published: July 3, 2013 \\ doi:10.5539/jms.v3n3p55 \\ URL: http://dx.doi.org/10.5539/jms.v3n3p55
}

\begin{abstract}
Over the years, employer branding has not enjoyed as much attention in the branding literature. This led the researchers to try to locate a theoretical and conceptual basis of employer branding based on a review of the literature. As such, the literature revealed seven applicable models which collectively recommend that examining the subject only in terms of external branding efforts and processes is both limiting and misleading. Rather, the subject should also be examined from the perspective of internal branding processes. This finding was further buttressed by the tenets of activity theory - which formed the theoretical basis of analyzing the present concern. Further examination of the literature revealed the need for employer branding factor determination and contextualization of employer branding models - leading to the proposed model in this study based on the theoretical findings in the literature. Finally, recommendations for empirical validation of the theoretical findings for further studies were made.
\end{abstract}

Keywords: employer branding, activity theory, employee perception

\section{Introduction}

For a long time, branding has merely been concerned with endearing customers to a product/service and sustaining brand loyalty. It was taken for granted that a strong brand requires efficient employees who work seamlessly to actualize the brand's vision. The issue for employers thus becomes, how to strategically attract and engage employees who believe in the goals and aspirations of the organization and are efficient enough to bring their resources into ensuring the success of the brand. The importance of human capital management has become of much relevance that employers now believe that the success of the organization lies in its people. Employer branding, therefore, is understood as the set of distinctive images of a prospective employer, which is manifest in the minds of the target people - potential employees (Meffert, Barmann, \& Koers, 2002; Perkoric, 2004). As competition in the labour market has intensified, companies have also shown an even greater interest in strategies to differentiate themselves (Corporate Leadership Council, 1999). In addition, strong demand in specific skills as well as an ever tightening labour market is making it much more difficult to retain current employees and to recruit new employees.

Creating the desired perceptions among current employees therefore, provides them with the disposition to send the right cues to customers. A sub-set of this general description of customer are potential employees. Current and potential employees gain greater significance through the understanding that a saturation of the best talents in a single organization under a well managed organizational structure attracts more business to that organization thereby posing a critical threat to competitors. As a result, firms within and across industry sectors are constantly caught in the quest for talent. Indeed, government parastatals and agencies are not left out in this contest for the best hands in areas of strategy and public policy, amongst others; for even governments are gradually becoming more aware of the competitiveness between nations and the realization of the immerse benefits of knowledge-based economies towards overcoming the growing challenges of a more complex future.

\section{Employer Branding}

Corporate organizations have placed so much emphasis on developing their product brands through advertising, sales promotion, direct marketing, internet marketing and other tools in the promotion mix with the aim of 
favourably placing their brands in the minds of consumers (Branham, 2001). While so much was done to attract consumers, little attention was paid to employees. This has had serious repercussions on the ability of employers to attract and retain talented employees. The internal marketing concept argues that the organization's personnel are the first market of any company (George \& Gronroos 1989; George 1990). Likewise, employees are directly affected by the activities of the organization. Employer branding came about as a result of the inability of employers to attract and retain talents and the concept has since witnessed gradual development and interest within organizations all over the world. However, many organizations are yet to fully understand the importance of engaging in employer branding activities.

In coming to terms with the above-mentioned realities, employers use employer branding processes to enhance their corporate identity and position themselves in the employment market with strong differentiation from their competitor-employers. The aim is to create a sensational and emotional image about an employer in the minds of current and prospective employees. It has also been defined as the package of psychological, economic, and functional benefits provided by employment and identified with an employer (Thorne, 2004). If one adopts the internal marketing view that employment opportunities are one of the products offered by the firm (e.g. Sasser \& Arbeit, 1976), models of consumer behaviour may be applied to the employment market. Similarly, job evaluations may be influenced by search, experience, and trust characteristics, in the same way that market information, prior experience, and trust in the brand influence product evaluations (Franck, Pudack, \& Opitz, 2001; Schmidtke, 2002; Teufer, 1999). This will imply that potential employees can directly observe certain characteristics of a job offer, such as location and salary.

However, other characteristics, such as work climate and employee orientation within the company, cannot normally be observed by potential employees ex ante. In assessing the attractiveness of a prospective employer, potential employees incur costs associated with seeking the information necessary to make an informed decision. They may search for observable information directly and/or make use of (sometimes, inappropriate) information substitutes. Searching for observable information is only possible for search characteristics such as location and salary. For experience and trust characteristics (e.g. career development, performance-based remuneration, and work climate), the potential employee needs to make use of information substitutes such as brand signals (Weiber \& Adler, 1995). As identified by Lievens (2007), no study has explored employer brand beliefs of different groups of individuals capturing both potential and current employees although, previous researchers (Maxwell \& Knox, 2009; Lievens 2007) have highlighted what makes up an attractive employer brand. In spite of these contributions, it appears that limited attention has been given towards understanding the relationship that exists between employer branding on the one hand and perceptions of current and potential employees on the other. The need for more research is found even more wanting in particular contexts (firms) with their operations defined by the eccentricities of their environments. This background led the researchers to the concern of this study, how is employer branding used to create the desired perceptions among current and potential employees? The first step in answering this question is to gain a more coherent understanding of the construct from the contributions in the literature.

\section{Employer Branding Models}

Backhaus \& Tikoo (2004) indicate that employer branding creates two principal assets: brand associations and brand loyalty. Employer brand associations shape the employer image which in turn affects the attractiveness of the organization to potential employees. Employer branding impacts the organization culture and organization identity which in turn contributes to employer brand loyalty. At the same time, the model emphasizes that organizational culture feeds back to the employer brand, while employer brand loyalty contributes to increasing employee productivity. According to the model, brand loyalty can be shaped by a behavioural element that relates to organizational culture and an attitudinal element that relates to organizational identity. 


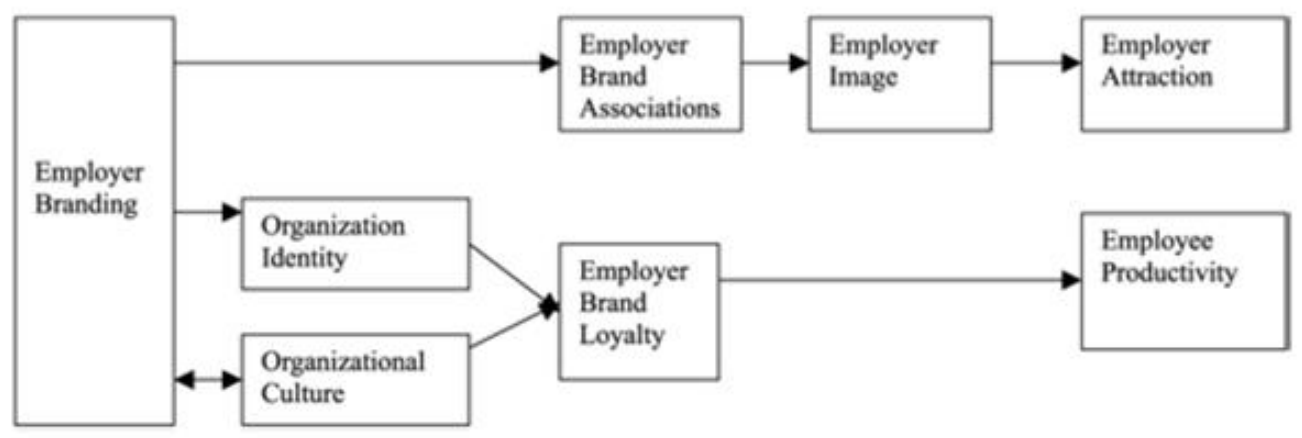

Figure 1. Employer branding framework (Backhaus and Tikoo, 2004)

On the other hand, Knox and Freeman (2006) propose a recruitment process model which shows the perception of potential recruits and recruiters on the employer brand image of a firm. The employer brand image of an organization (in this case, an international service provider) is measured externally by potential recruits and internally by their recruiters. The model shows the important role of interpersonal communication between employees and external groups in shaping attitudes and image than any communication sponsored by the firm itself (Dowling, 2002). Mosley's (2007) employer brand experience framework however, brings a new twist to studies in employer branding as it shows the weaknesses of employer branding aimed solely at communicating brand promises at the expense of longer term management of employee experience. The model applies a rarely predictable sequence of employee "touch-points" which makes customer experience consistent and distinctive. This experience depends heavily on interpersonal interactions. The firm will need to ensure that its employer-brand attracts the right kind of people and the employer-brand-management reinforces the right kind of culture. The employer-brand-experience is intended to help engender a distinctive brand attitude, generate distinctive brand behaviors and ultimately reinforce the kind of distinctive customer service style that will add value to the customer experience and differentiate an organization from its competitors.

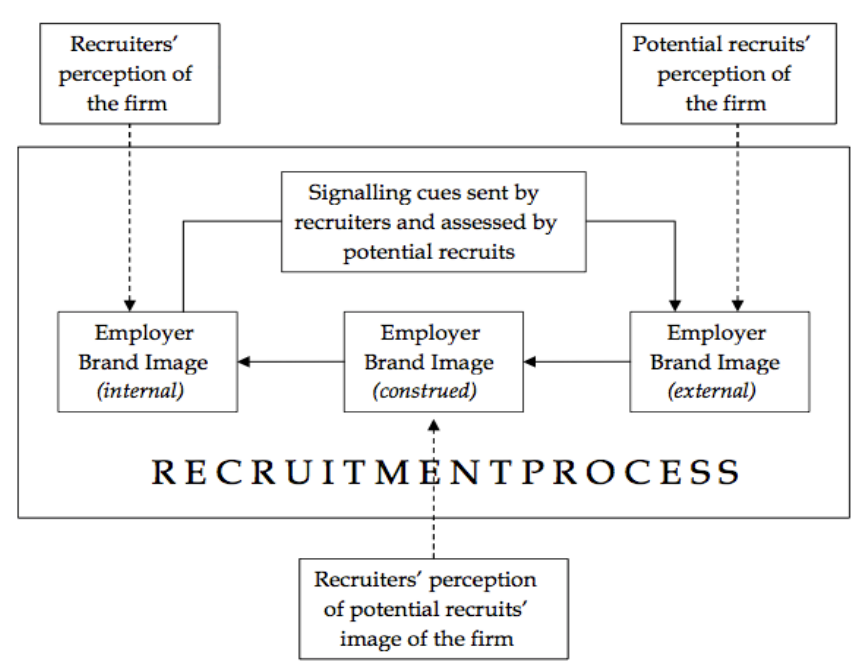

Figure 2. Employer brand recruitment process model (Knox \& Freeman, 2006) 


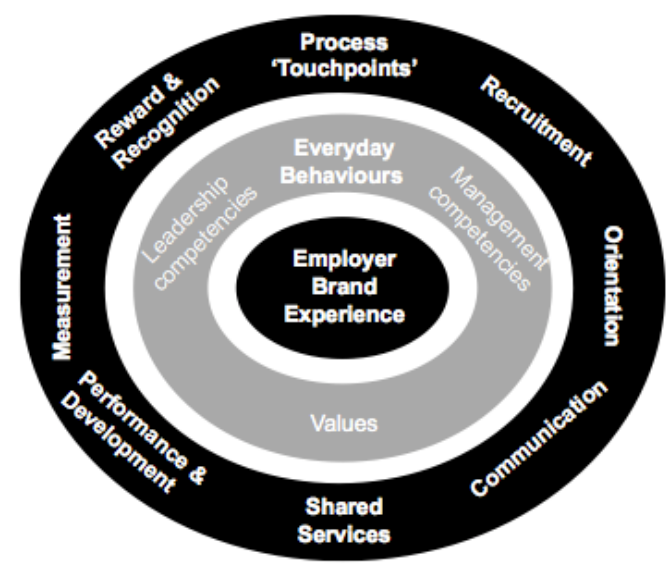

Figure 3. Employer brand experience framework (Mosley, 2007)

Maxwell \& Knox (2008) present an "employer categories and attributes schema". Their model illustrates the attributes that employees find very attractive in organizations and how these attributes differ from organization to organization. This inconsistency has been attributed in some way to the understanding that each organization possessed unique attributes that employees found very attractive. The attributes that employees considered important, whether attractive or unattractive, fell into four categories: employment, organizational success, construed external image and attributes of the product or service. Using the social identity theory to examine five organization Maxwell \& Knox (2008) discovered that the specific attributes considered most attractive by employees were different in each organization. However, the categories of attributes were identical: employment, organizational success, construed external image and product or service characteristics. In contrast, Tuzuner \& Yuksel (2009) suggest a demographic and attractiveness model which focuses on the first step of employer branding concept, referred to as the "employer attractiveness" phase. The model is tailored based on the expectations of potential employees considering such factors as demographic characteristics, attractiveness components of firms in employer branding concept and clusters. The demographic characteristics according to the model refer to gender and age specifically. "Integrated employer branding" refers to the extent to which an individual is attracted to an employer that provides many integrating alternatives in working environment such as: possibility for advancement/promotion, task that mean bigger challenges, innovative solutions, strong clear company culture, market success, internal further education, inspiring colleagues, international career opportunities, work/life balance, project based work, good reputation and so on. "Competitiveness" refers to the extent to which an individual is attracted to an employer that provides competitive work environment, competitive compensation package and the possibility of working from home. 


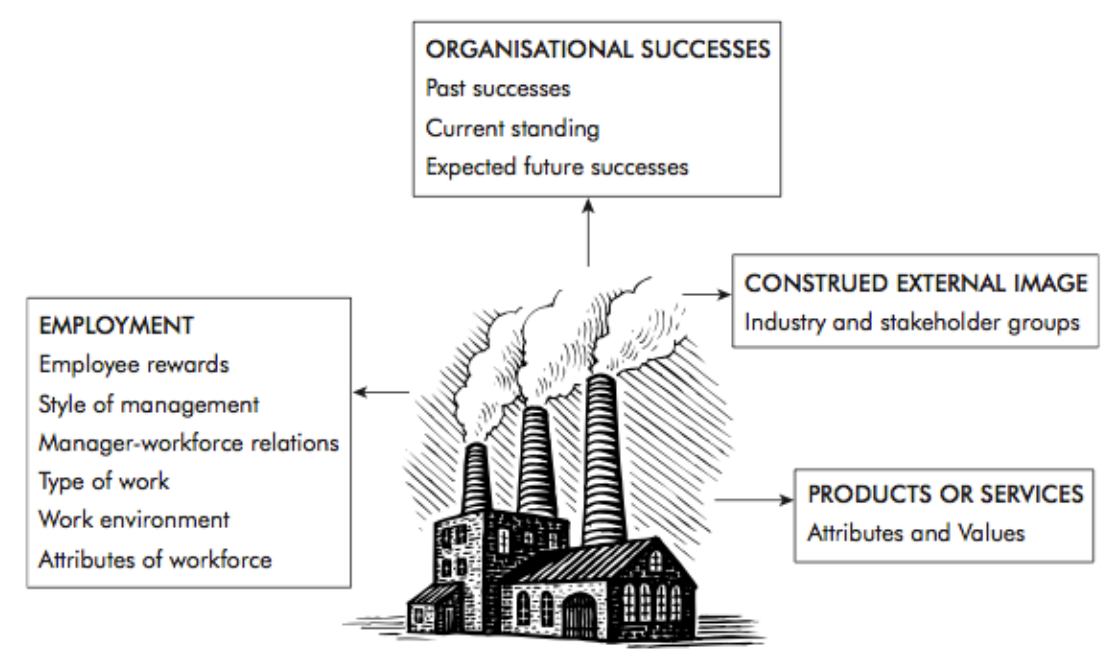

Figure 4. Employer categories and attributes schema (Maxwell and Knox, 2008)

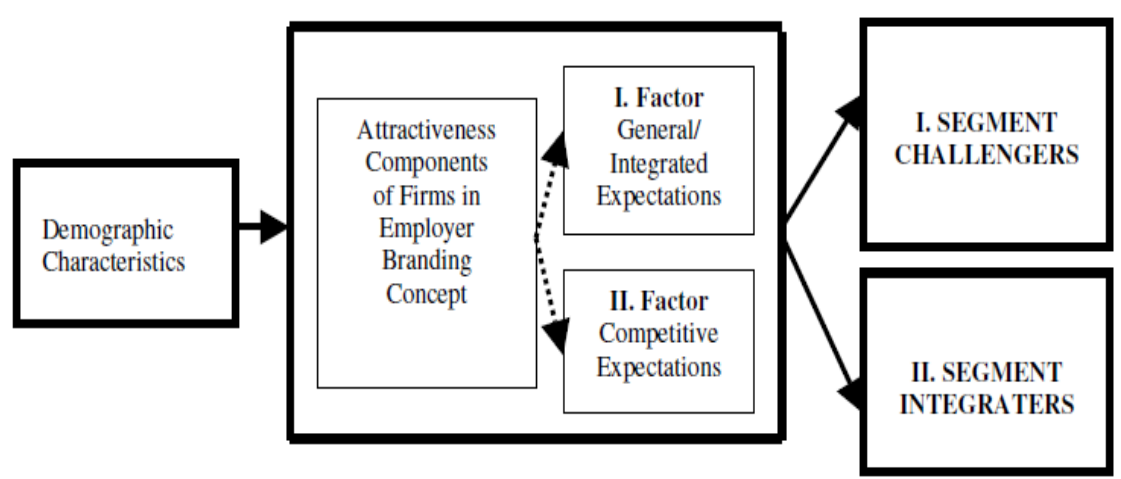

Figure 5. Demographic and attractiveness model (Tuzuner \& Yuksel, 2009)

Wilden (2010) discussed the conceptual framework for employee-based brand equity. A framework was developed, which portrays the potential employee as the uninformed party, who is uncertain about the quality of employment with the prospective employer. The work presented a conceptual framework for employee-based brand equity, modified from previous consumer-based branding research examining the role of brand signals on consumer's evaluation of product quality (Erdem et al., 1999). Relating internal marketing to employment opportunities as product offered by a firm, it is possible to apply models of consumer behavior to the employment market. As mentioned earlier, job evaluations may be influenced by search, experience, and trust characteristics in the same way product evaluations are influenced by market information, prior experience and trust in the brand (Franck, Pudack \& Opitz, 2002). Not all the information about a job is available to potential employees. While they may have access to a firm's location and salary structure, they may not know about the work climate and employee orientation within the company. To this end, potential employees incur a lot of cost while trying to secure necessary information to make a well informed decision. This makes it necessary for potential employees to employ the use of information substitute such as brand signals (Weiber \& Adler, 1995).

Employer branding strategies can be used to make brand signals convey the desired message to the employee market, while also reducing information cost to potential employees. According to Berthon, Ewing \& Hah (2005), employer attractiveness is the set of envisioned benefits that a potential employee sees in working for a specific organization. Employer attractiveness is an important element of employee-based brand equity which is created by the signals sent out by the organization. According to this model, Erdem \& Swait (1998) proposed that the clarity of a brand signal is determined by unambiguous information conveyed by the employer brand. 
Clear communication of the employer brand and absence of bias in brand signals give rise to a credible position in the employment market and also reduces information cost for potential employees. According to Tirole (1999), credible brand signals convey information that has greater potential in reaching the target group. The perception of potential employees about the credibility of employer brand signals is dependent on their evaluation of the trustworthiness of the prospective employers. This model shows that if a signal is credible and the prospective employer is considered trustworthy, potential employees associate decreased risk with employment by the firm, and gain comfort from the expectation that promises made by the company are likely to be fulfilled.

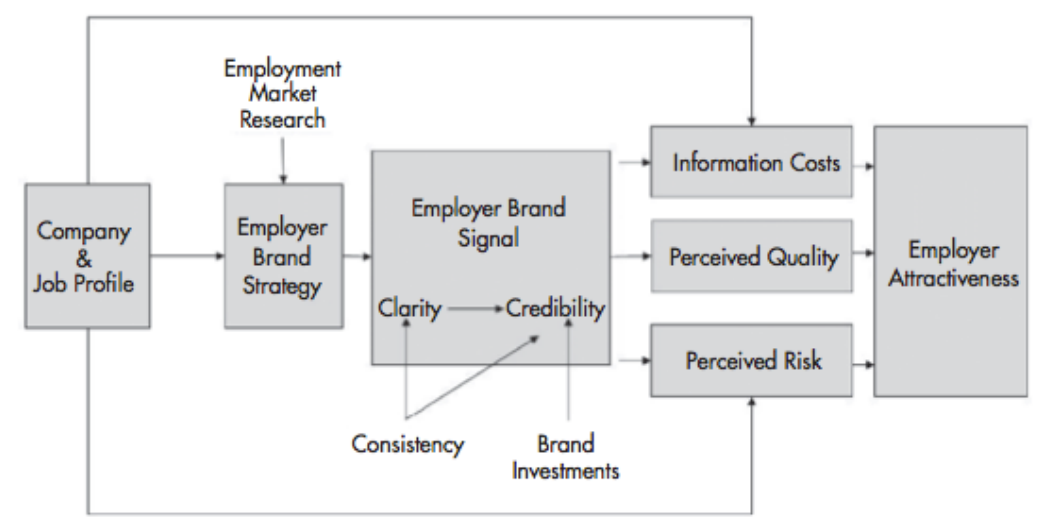

Figure 6. Employee-based Brand Equity Model (Wilden et al., 2010)

Mandhanya \& Shah's (2010) “employee branding process" model shows how employer branding can be utilized for talent management. The process of talent management begins by creating employer branding; employer branding is a two-fold process which comprises one for current employees and the other for potential employees. For potential employees, employer branding is targeted at building a reputation for the company as the preferred place to work, while internal branding for current employees requires that the company lives up to its standard and incorporate a culture of respect and trust for employees. The model shows that potential employees develop an employer brand image from the brand associations that are an outcome of a firm's employer branding. Employer branding helps to create brand associations and brand loyalty. Employer brand associations shape the employer image that in turn affects the attractiveness of the organization to the potential employees. Employer branding impacts organizational culture and organizational identity that in turn contributes to employer branding loyalty. This loyalty in turn retains employees and helps the organization to manage talent.

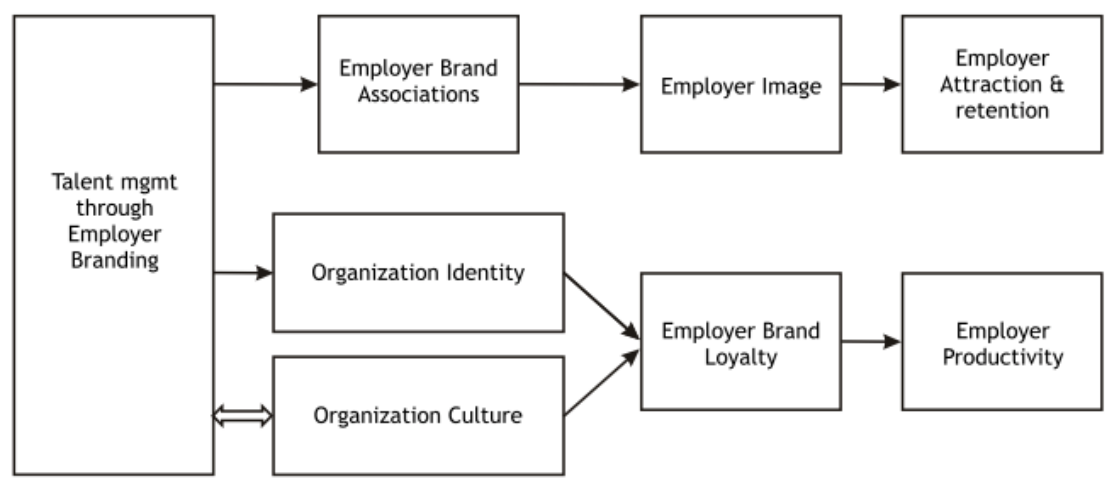

Figure 7. Employee Branding Process Model (Mandhanya \& Shah, 2010)

Some of the research carried out in the field of employer branding have attempted to bring out characteristics of successful employer brands. Amongst such is a study conducted by Moroko \& Uncles (2008) in which attractiveness and accuracy were identified as the two key dimensions of success for an employer brand. Accuracy was analyzed in terms of employer brand awareness, differentiation and relevance while accuracy was 
underpinned by factors such as the importance of consistency between the employer brand and the employment experience as well as company culture and values (especially as regards the lack of understanding of company value which potential employees suffer before joining the organization). The analysis of these authors shows that there are two key dimensions of success for an employer brand: "attractiveness" and "accuracy". Attractiveness is underpinned by "awareness", "differentiation" and "relevance". Accuracy highlights the importance of consistency between the employer brand and employment experience, company culture and values. The study established a case for studying employer branding as a context distinct from consumer and corporate branding and conceptualized the employment experience of a firm as a product produced by the culture, policies and processes of the firm. It also established that there are many well-worn parts in marketing theory and practice that are applicable to employer branding context, particularly with respect to the employee attraction role of the employer brand.

Other researchers have studied employer branding as it relates to the recruitment process (e.g. Knox \& Freeman, 2006), or as it relates to the army, with emphasis on the instrumental and symbolic beliefs of employees (Lievens, 2007). Lievens, for instance, examined the relative importance of instrumental and symbolic beliefs across different groups of individuals: potential applicants, actual applicants and military employees. The study discovered that 1) the set of instrumental job and organizational attributes and symbolic trait inferences are significantly related to the army's attractiveness as an employer, 2) perception of instrumental attributes explain significantly more variance (40\%) in the army's perceived attractiveness as an employer among actual applicants compared to potential applicants and employees, 3) symbolic trait inferences played an important role in determining attractiveness among all three groups, 4) actual applicants have considerably more favourable perceptions about an employer's instrumental and symbolic attributes than potential applicants and employees.

However, in spite of these contributions, it appears limited attention has been given towards understanding the relationship that exists between employer branding on the one hand, and perceptions of current and potential employees on the other, especially as it relates to specific contexts. Many researchers have not considered that employer branding is not just concerned with attracting employees but also in retaining and motivating them. Hence, the determining factors used to analyze employees might not be applicable to both current and potential employees. Also, researchers on the subject have not fully addressed the influence employer branding has on perception of employees notwithstanding that existing contributions have been instrumental in the development of this research work. Finally, no scale has been provided in literature that can fully capture all the components of employer branding.

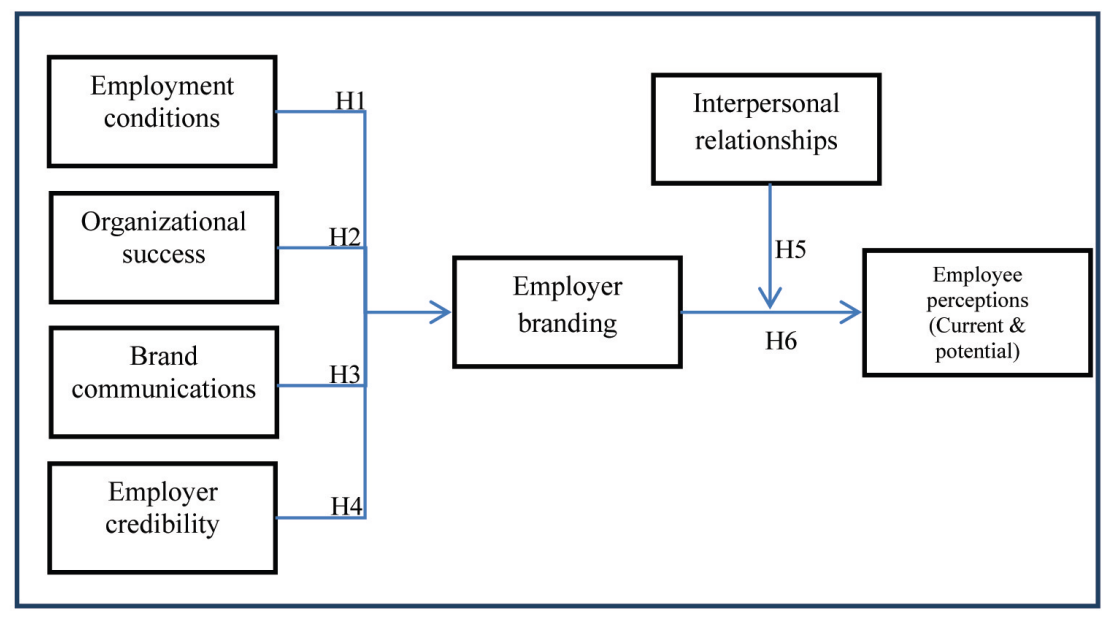

Figure 8. Employer branding conceptual framework operationalised through interpersonal relationships

\section{Activity Theory}

The discovery of the several gaps in the literature identified in (3) above, inspires the necessity to interrogate the theoretical foundation of the existing models. Situating an appropriate theoretical background on the other hand, requires a theory which captures all the elements of the emerging model (see Figure 8) which consists of three main elements: the independent variable (employer branding), the mediating variable (interpersonal relationships) 
and the dependent variable (current and potential employee perceptions). Therefore, activity theory seems best suited as the theoretical basis for this study given the antecedent of its cultural-historical development as well as its collectivism bias. The theory is found on the principle of contextual basis of analysis as opposed to isolated instances of actions as the basis for human understanding. In effect, for each instance of analysis, it is essential to adopt a semantic-minimalist approach; for it would be ineffective, if not outrightly futile, for a theory to argue for contextual analysis where each unit of analysis is vagrantly overreaching. Within this first principle of contextual basis, is located, three levels of understanding: historical development, artefacts and mediation. These levels lead to the key elements of the theory (subject, tool and object) which result in the outcome. Again, these three key elements are further expandable to six elements (subject, object, mediating instrument, rules, community and division of labour) - a relationship which better captures the operating entity of larger systems or organizations (see Figure 9).

In view of this background, the first step in theory application is to understand what is meant by historical development within contextual analysis. The mere term, "activity" implies a discontinuous, evolution which is founded on a plot. Hence, the story of the growth of a firm governs the boundaries of its present culture, ethos, values and actions - and in effect, the actions of those (employees) who drive its actions. The same applies to the relationship between individuals' historical antecedents and their present actions. By extension, a commonality of culture and values is often sought between organizations and current and potential employees. While they may not necessarily share similar (how much more common) history, it would be safe to conclude that however variant, divergent histories could lead to shared values. The second and third aspects (artefacts and mediation) are very closely related yet separable - given that on one side stands the artefacts in the sense of tools and instruments while on the other, stands the functionality of these tools which convey the action(s) to the object. As such, they play a mediating role between the subject and the object.

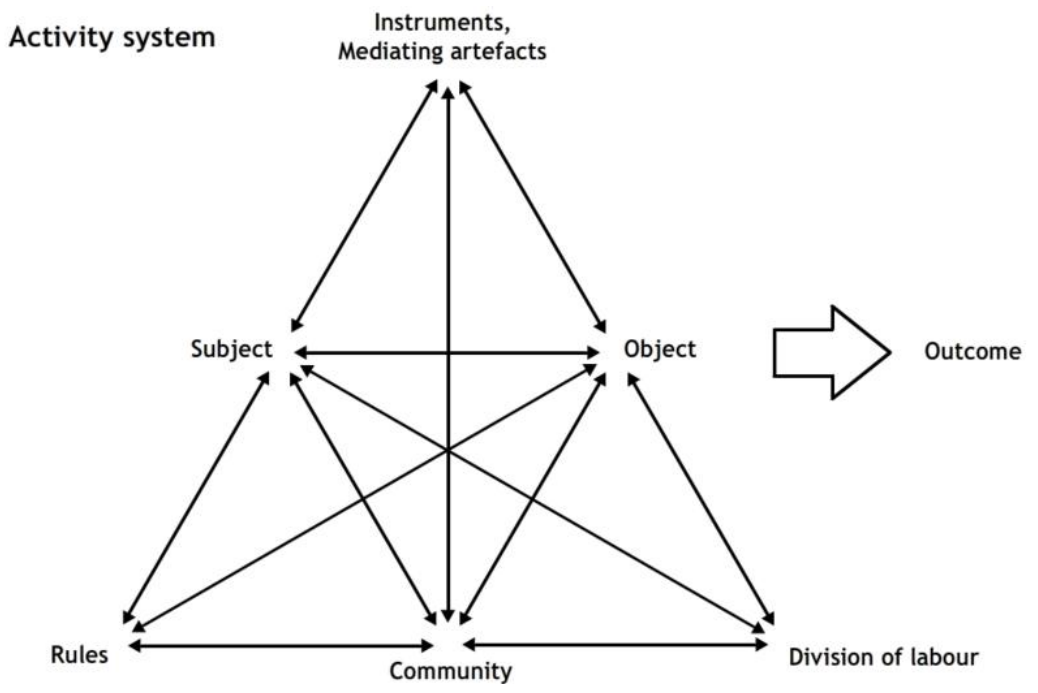

Figure 9. Activity theory model (Engeström, 1987)

Therefore, we find that as it relates to the current study, the object is the independent variable (employer branding), which comprises of: employment conditions, organizational success, brand communications, employer credibility. The activity refers to the subtotal of the elements involved in the employer branding process. The subject refers to the desired perceptions of current and potential employees about an organization. The tool (artefacts) in this study is the mediating variable: interpersonal relationships. This implies that organizations do not just function in isolation. Rather, such actions are based on the interconnectivity of several other actions aimed at accomplishing a desired result. In clear terms, the firm engages in different actions aimed at creating desired perceptions among its current and potential employees; thereby making it an employer of choice. Thus, employer branding motivates and gives rise to desired perceptions among current and potential employees of the brand, while interpersonal relationships serves as the mediating variable between employer branding and the desired perceptions. In effect, as the history of the firm evolves, so also would all the elements (rules, community, division of labour, instruments, subject and object) evolve to reflect the present stage in the 
plot of the firm; by so doing, the firm's evolution continues to capture a workforce which incorporates and is incorporated in its value system leading to the attainment of desired outcomes.

\section{Conclusion}

This research sought out to find out how employer branding has been treated in the literature vis-à-vis the creation of desired perceptions among current and potential employees. A review of the literature reveals seven relevant models which form the basis of understanding employer branding stages and processes. However, as earlier mentioned, the literature lacks the application of existing models to specific contexts. As a result, the researchers continue to question the universality of the suggested employer branding factors. Insight gained from activity theory, as the theoretical basis for understanding employer brand, shows that in the larger organizational structure, other context-specific factors do not just come to play in employer branding, but require critical examination. These factors include the community (internal and external), the rules which govern the conduct and operations of the firm as well as its interactions with external communities. Division of labour involves the roles of different members of the firm and the limitation of responsibilities and functions. All of these factors make up an enduring relationship which subsists for desired outcomes.

Further research is therefore needed to establish the relationship between employer branding and other constructs - more especially the concern of this study: the perceptions of current and potential employees. Research could also examine the relationship between employer branding and constructs such as profitability and share value given that building a strong employer brand may likely increase positive perceptions of the brand as a whole to stakeholder groups outside (current and potential) employees. Finally, there is the need for scale development in measuring the relationship between employer branding and other constructs. Such research efforts will be useful to organizations in determining which employer branding factors indicate higher associations with (current and potential) employee perceptions. A qualitative study of managers and customers may also reveal other factors which make up employer branding. As such, the researchers admit that the factors proposed in this study (employment conditions, organizational success, brand associations and employer credibility) are not entirely exhaustive. Admittedly, there is also the possibility of other mediating variables which may affect the relationship between employer branding and (current and potential) employee perceptions. Such a possibility is best determined through extensive qualitative research. Given the importance of employer branding on employee perceptions, the results of further (empirical) studies could better inform organizations on how to strategically brand their companies for the benefit of gaining scarce talents.

\section{References}

Ambler, T., \& Barrow, S. (1996). The employer brand. Journal of Brand Management, 4(3), 185-206.

Ashforth, B. E., \& Mael, F. (1989). Social identity theory and organization. Academy of Management Review, 14(1), 20-39.

Babbie, E. R. (1992). The practices of social research. Belmont, CA: Wadworth.

Backhaus, K., \& Tikoo, S. (2004). Conceptualizing and researching employer branding. Career Development International, 9(4/5), 501-517. http://dx.doi.org/10.1108/13620430410550754

Balmer, J. M. T. (1995). Corporate branding and connoisseurship. Journal of General Management, 21(1), 24-47.

Balmer, J. M. T. (2001). Corporate identity, corporate branding and corporate marketing: seeing through the fog. European Journal of Marketing, 35(3/4), 248-270. http://dx.doi.org/10.1108/03090560110694763

Balmer, J. M. T., \& Gray, E. (2003). Corporate brands: what are they? what of them? European Journal of Marketing, 37(7/8), 972-998. http://dx.doi.org/10.1108/03090560310477627

Balmer, J., \& Greyser, S. (2006). Corporate marketing: integrating corporate identity, corporate branding, corporate communications, corporate image and corporate reputation. European Journal of Marketing, 40(7/8), 730-741. http://dx.doi.org/10.1108/03090560610669964

Barrow, S., \& Mosley, R. (2005). The employer brand. London: Wiley \& Sons Limited.

Bentler, P. M. (1990). Comparative fit indexes in structural models. Psychological Bulletin, 238-246.

Berthon, P., Ewing, M., \& Hah, L. L. (2005). Captivating company: dimensions of attractiveness in employer branding. International Journal of Advertising, 24(2), 151-172.

Bogdan, R. B., \& Biklin, S. K. (1998). Qualitative research for education: an introduction to theory and methods (3rd ed.). Massachusetts: Allyn and Bacon. 
Branham, L. (2001). Keeping the people who keep you in business: 24 ways to hang on to your most valuable talent. New York: American Management Association.

Brickson, S. (2005). Organizational identity orientation: forging a link between organizational identity and organisations' relations with stakeholders. Journal of Marketing Management, 25, 576-609.

Dutton, J., Dukerich, J., \& Harquail, C. (1994). Organizational images and member identification. Administrative Science Quarterly, 39, 239-263.

Engeström, Y. (1987). Learning by expanding: an activity-theoretical approach to developmental research (Helsinki, Orienta-Konsultit).

Ewing, M. T., Pitt, L. F., de Bussy, N. M., \& Berthon, P. (2002). Employment branding in the knowledge economy. International Journal of Advertising, 21(1), 3-22.

Fisher, C. D., IIgen, D. R., \& Hoyer, W. D. (1979). Source credibility, information favorability and job offer acceptance. Academy of Management Journal, 22, 94-103. http://dx.doi.org/10.2307/255481

Fulmer, I. S., Gerhart, B., \& Scott, K. S. (2003). Are the 100 best better? An Empirical Investigation of the Relationship between being a "Great place to work" and Firm's Performance. Personnel Psychology, 56, 965-993.

Highhouse, S., \& Hoffman, J. R. (2001). Organizational attraction and job choice. In C. L. Cooper \& I. T. Robertson (Eds.), International Review of Industrial and Organizational Psychology (pp. 37-64). Chichester: Wiley.

Highhouse, S., Thornbury, E. E., \& Little, I. S. (2007). Social-identity functions of attraction to organizations. Organizational Behavior and Human Decision Processes, 103(1), 134-146. http://dx.doi.org/10.1016/j.obhdp.2006.01.001

Highhouse, S., Zickar, M. J., Thorsteinson, T. J., Stierwalt, S. L., \& Slaughter, J. E. (1999). Assessing company employment image: An example in the fast food industry. Personnel Psychology, 52, 151-172.

Keller, K. L. (1993). Conceptualizing, measuring, and managing customer-based brand equity. Journal of Marketing, 57, 1-22.

Keller, K. L. (1998). Strategic brand management. Upper Saddle River, NJ: Prentice Hall.

Knox, S., \& Freeman, C. (2006). Measuring and managing employer brand image in the service industry. Journal of Marketing Management, 22, 695-716. http://dx.doi.org/10.1362/026725706778612103

Knox, S., \& Maklan, S. (1998). Competing on Value. London: Financial Times, Pitman Publishing.

Lievens, F., \& Highhouse, S. (2006). The relation of instrumental and symbolic attributes to a company's attractiveness as an employer. Personnel Psychology, 56(1), 75-102. http://dx.doi.org/10.1111/j.1744-6570.2003.tb00144.x

Lievens, F., Van Hoye, G., \& Anseel, F. (2007). Organizational identity and employer image: towards a unifying $\begin{array}{lllll}\text { framework. British Journal of } & \text { Management, }\end{array}$ http://dx.doi.org/10.1111/j.1467-8551.2007.00525.x

Lloyd, S. (2002). Branding from the inside out. Business Review Weekly, 24(10), 64-66.

Mandhanya \& Shah. (2010). Employer branding: a tool for talent management. Global Management Review, $4(2), 43-48$.

Maxwell, R., \& Knox, S. (2009). Motivating employees to "live the brand": a comparative case study of employer brand attractiveness within the firm. Journal of Marketing Management, 25(9-10), 893-907. http://dx.doi.org/10.1362/026725709X479282

Moroko, L., \& Uncles, M. (2008). Characteristics of successful employer brands. Brand Management, 16(3), 160-176. http://dx.doi.org/10.1057/bm.2008.4

Moroko, L., \& Uncles, M. (2009). Employer branding and market segmentation. Brand Management, 17(3), 18-196. http://dx.doi.org/10.1057/bm.2009.10

Mosley, R. (2007). Customer experience, organizational culture and the employer brand. Brand Management, 15(2), 123-134. http://dx.doi.org/10.1057/palgrave.bm.2550124

Tuzuner, V. L, \& Yukse, C. R. (2010). Segmenting potential employees according to firm's attractiveness dimensions in the employer branding concept. Journal of Academic Research in Economics, 47-60. 
Tyler, T., \& Blader, S. (2000). Cooperation in groups: procedural justice, social identity and behavioral engagement. Philadelphia, PA: Psychology Press.

Uncles, M., \& Moroko, L. (2005). Employer branding: the case for a multidisciplinary process-related empirical investigation. In G. Sutar \& J. Sweeney (Eds.), Broadening the Boundaries (pp. 52-57). Perth: ANZMAC Conference Proceedings.

Vygotsky, L. S. (1994). The problem of the environment. In R. van der Veer \& J. Valsiner (Eds.), The Vygotsky Reader (pp. 338-354). Cambridge: Blackwell.

Wilden, R., Gudergan, S., \& Lings, I. (2006). Employee-based brand equity. In Drennan, J. (Ed.), Proceedings of ANZMAC 2006. QUT, Brisbane (47).

Wilden, R., Gudergan, S., \& Lings, I. (2010). Employer branding: strategic implications for staff recruitment. Journal of Marketing Management, 26(1-2), 56-73. http://dx.doi.org/10.1080/02672570903577091

\section{Copyrights}

Copyright for this article is retained by the author(s), with first publication rights granted to the journal.

This is an open-access article distributed under the terms and conditions of the Creative Commons Attribution license (http://creativecommons.org/licenses/by/3.0/). 